\title{
PENGARUH E-SERVICESCAPE DAN ADVERTISING EFFECTIVENESS TERHADAP SHOPPING EMOTION DAN PEMBELIAN IMPULSIF
}

\author{
Gunarso Wiwoho \\ Email: gunarsowiwoho@yahoo.com
}

\begin{abstract}
Abstrak
Penelitian ini bertujuan untuk mengetahui pengaruh dari e-servicescape dan advertising efeectiveness terhadap shopping emotion dan pembelian impulsif pada pengguna Shopee di Kebumen. Pengumpulan data dilakukan dengan kuesioner. Dengan menggunakan teknik non-probability sampling, penelitian ini mengambil sampel 100 responden konsumen Shopee. Variabel yang digunakan pada penelitian ini adalah e-servicescape (X1), advertising efeectiveness (X2), shopping emotion (Y1) dan pembelian impulsif (Y2). Penelitian ini menggunakan teknik analisis data menggunakan teknik analisis deskriptif dan statistik meliputi uji validitas, uji reliabilitas, uji asumsi klasik, uji hipotesis, analisis jalur dan analisis korelasi dengan menggunakan bantuan program SPSS 22 for windows. Hasil penelitian ini menunjukan bahwa semua variabel valid dan reliabel, tidak terdapat multikolinieritas, tidak terjadi heteroskedastisitas dan model memenuhi asumsi normalitas. Pengaruh e-serivescape terhadap shopping emotion menunjukkan pengaruh positif dan signifikan terhadap shopping emotion. Pengaruh advertising effectiveness terhadap shopping emotion menunjukkan pengaruh yang positif dan signifikan terhadap shopping emotion. Pengaruh e-serivescape terhadap pembelian impulsif menunjukkan pengaruh yang positif namun tidak signifikan terhadap pembelian impulsif. Pengaruh advertising effectiveness terhadap pembelian impulsif menunjukkan pengaruh yang positif dan signifikan terhadap pembelian impulsif. Pengaruh shopping emotion terhadap pembelian impulsif menunjukkan pengaruh yang positif dan signifikan terhadap pembelian impulsif.
\end{abstract}

Kata Kunci: E-Servicescape, Advertising Efeectiveness, Shopping Emotion dan Pembelian Impulsif.

\section{PENDAHULUAN}

Internet telah berkembang menjadi ajang komunikasi yang sangat cepat dan efektif. Hidup manusia semakin lebih mudah dengan adanya internet. Salah satu kemudahannya ialah dapat berbelanja kapan pun dan dimana pun pada saat dibutuhkan yaitu dengan berbelanja online. Aktivitas berbelanja online mulai menjadi budaya tersendiri di Indonesia. Cukup dengan terhubung dengan internet, kita bisa langsung melihat barang-barang yang dapat kita pilih secara online dan mendapatkan barang yang kita inginkan. Banyak kemudahan dalam berbelanja secara online dewasa ini. Selain itu, berbelanja secara online dapat mempersingkat waktu belanja kita karena tidak memerlukan banyak waktu untuk menuju lokasi toko tujuan kita.

Perubahan pola perilaku pembelian dari yang serba offline menjadi serba online menjadi salah satu pendorong terbentuknya e-commers. Berbagai e-commers muncul dengan berbagai ciri dan keunggulan masing-masing. Kebutuhan dan keinginan masyarakat yang makin beragam memberikan peluang bagi perusahaan untuk menyediakan kebutuhan dan keinginan tersebut. Kecenderungan masyarakat Indonesia yang konsumtif juga menjadi peluang bagi bisnis e-commers untuk terus mengembangkan bisnisnya dalam memenuhi kebutuhan konsumen, salah satunya dengan munculnya marketplace
Salah satu contohnya adalah Shopee. Shopee resmi hadir pada Desember tahun 2015 di Indonesia dibawah naungan PT Shopee International Indonesia. Sejak peluncurannya, Shopee Indonesia mengalami perkembangan yang sangat pesat, bahkan hingga Oktober 2017 aplikasinya sudah didownload oleh lebih dari 43 juta pengguna. Yang mana aplikasi ini tersedia di platform iOS dan Android.

Marketplace merupakan kegiatan yang dalam proses jual-beli terlibat didalamnya penjualan barang secara langsung kepada konsumen akhir. Marketplace dewasa ini dikelola dengan modern. Penggunaan website maupun aplikasi menjadi ujung tombak penjualan. Sistemnya pun kian hari kian mengalami perbaikan seiring berjalannya waktu.

Munculnya berbagai perusahan marketplace di Indonesia dengan berbagai keunggulan yang ditawarkan. Penciptaan suasana yang sedemikian nyaman membuat konsumen rela menghabiskan waktu dan uang untuk berbelanja

\section{METODE}

\section{Definisi Operasional Variabel}

Pembelian impulsif (impulse buying) didefinisikan sebagai tindakan membeli yang sebelumnya tidak diakui secara sadar sebagai hasil dari suatu pertimbangan, atau 
niat membeli yang terbentuk sebelum memasuki toko (Mowen \& Minor, 2002:10).

Harris dan Goode (2010) menyatakan bahwa Online servicescape merupakan suatu atmosfer lingkungan dalam sebuah ruang virtual online yang dirasakan oleh pengunjung situs pada saat mereka menjelajahi atau menerima layanan perusahaan melalui website yang dikunjungi.

Efektivitas Iklan adalah rangkaian yang memusatkan pada iklan itu sendiri, yaitu : pengenalan iklan, mengingat kembali iklan, menyampaikan iklan, dan menyukai serta percaya atas iklan. Ukuran-ukuran ini berkaitan dengan ukuran-ukuran yang dipusatkan pada merek di seluruh gambaran evaluasi iklan karena ukuran tersebut digunakan dalam proses eliminasi untuk menilai apakah iklan itu efektif, dan jika tidak untuk mengurangi apa yang keliru (Sutherland dan Sylvester, 2007).

Menurut Hetharie (2011) shopping emotion merupakan faktor perasaan atau emosi merupakan konstruk yang bersifat temporer karena berkaitan dengan situasi atau objek tertentu dan mentukan suatu pembelian oleh konsumen

\section{Metode Pengumpulan Data}

Metode pengumpulan data dalam penelitian ini adalah metode survey dengan menggunakan kuisioner dan wawancara kepada responden yang telah dijaring dengan teknik purposive sampling. Metode yang dilakukan dalam pengumpulan data adalah metode kuesioner. Kuesioner adalah daftar pertanyaan tertulis yang telah dirumuskan sebelumnya yang akan dijawab oleh responden. Kuesioner dipilih karena merupakan suatu mekanisme pengumpulan data yang efisien untuk mengetahui dengan tepat apa yang diperlukan dan bagaimana mengukur variable.

\section{HASIL DAN PEMBAHASAN}

\section{Gambaran Umum Shopee}

Shopee adalah platform perdagangan elektronik yang berkantor pusat di Singapura, dibawah naungan SEA Grup (sebelumnya dikenal dengan Garena) yang didirikan pada 2009 oleh Forrest Li. Shopee diluncurkan pertama kali pada tahun 2015, dan mulai masuk ke pasar Indonesia pada akhir bulan Mei 2015 dan mulai beroperasi pada akhir Juni 2015 di Indonesia. Shopee telah hadir di beberapa negara di kawasan Asia Tenggara seperti Singapura, Malaysia, Vietnam, Thailand, Filipina, dan Indonesia. Shopee Indonesia beralamat di Wisma 77 Tower 2, Jalan Letjen. S. Parman, Palmerah, Daerah Khusus Ibukota Jakarta 11410, Indonesia.

\section{Uji Validitas}

Uji Validitas untuk mengetahui tingkat kevalidan sebuah kuesioner sebagai alat ukur atau instrumen penelitian. Suatu kuesioner dinyatakan valid apabila pernyataan atau pertanyaan yang digunakan pada kuesioner tersebut mampu mengungkap sesuatu yang telah diukur oleh kuasioner tersebut. Hasil uji yang dilakukan menyatakan bahwa seluruh item pertanyaan yang dipakai pada variabel E-Servicescape, Advertising Effectiveness, Shopping Emotion dan Pembelian Impulsif dinyatakan valid (sah).

\section{Uji Reliabilitas}

Uji reliabilitas butir dilakukan dengan ketentuan jika $r$ alpha> 0,6 maka butir atau variabel tersebut reliabel dan sebaliknya jika $r$ alpha< 0,6 maka butir atau variabel tersebut tidak reliabel.

Tabel IV.8

Hasil Uji Reliabilitas

\begin{tabular}{llccc}
\hline No & \multicolumn{1}{c}{ Variabel } & r alpha & $\begin{array}{c}\text { Batas } \\
\text { Penerimaan }\end{array}$ & Keterangan \\
\hline 1 & E-Servicescape & 0,796 & 0,6 & Reliabel \\
2 & $\begin{array}{l}\text { Advertising } \\
\text { Effectiveness } \\
3\end{array}$ & 0,790 & 0,6 & Reliabel \\
& $\begin{array}{l}\text { Shopping } \\
\text { Emotion }\end{array}$ & 0,601 & 0,6 & Reliabel \\
& $\begin{array}{l}\text { Pembelian } \\
\text { Impulsif }\end{array}$ & 0,851 & 0,6 & Reliabel \\
\hline
\end{tabular}

Berdasarkan tabel di atas hasil analisis dapat dijelaskan bahwa seluruh variabel yang dipakai dalam penelitian ini dinyatakan reliabel (andal) karena nilai $\mathrm{r}$ alpha $>0,60$.

\section{Uji Asumsi Klasik}

Uji Multikolinieritas

Uji multikolinieritas bertujuan untuk menguji apakah model regresi ditemukan adanya korelasi antar variabel bebas (independen). Model regresi yang baik seharusnya tidak terjadi korelasi diantara variabel independen. Adapun hasil analisisnya adalah :

\begin{tabular}{|c|c|c|c|}
\hline Hasil & $\begin{array}{r}\text { Ta } \\
\text { Multikolinier } \\
\text { Coeff }\end{array}$ & $\begin{array}{l}\text { el } \\
\text { ss Sub Str } \\
\text { ents }^{\mathrm{a}}\end{array}$ & ural I \\
\hline N & Todo & Collinearit: & tatistic \\
\hline NO & Model & Tolerance & VIF \\
\hline 1 & E-Servicescape & 0,656 & 1,525 \\
\hline 2 & $\begin{array}{l}\text { Advertising } \\
\text { Effectiveness }\end{array}$ & 0,656 & 1,525 \\
\hline
\end{tabular}

Berdasarkan tabel coeficient di atas dapat dijelaskan bahwa pada bagian colinieritas statistic menunjukkan angka VIF tidak lebih besar dari 10 dan tolerance lebih dari 0,10 . Berdasarkan hasil tersebut dapat diketahui bahwa model regresi substruktural I ini tidak terdapat multikolinearitas, sehingga model dapat dipakai.

\section{Tabel IV.10}

Hasil Multikolinieritas Sub Struktural II Coefficients $^{\mathrm{a}}$

\begin{tabular}{clcc}
\hline \multirow{2}{*}{ No } & \multicolumn{2}{|}{ Model } & \multicolumn{2}{c}{ Collinearitas Statistic } \\
\cline { 3 - 4 } & & Tolerance & VIF \\
\hline 1 & E-Servicescape & 0,495 & 2,040 \\
2 & Advertising Effectiveness & 0,524 & 1,909 \\
3 & Shopping Emotion & 0,413 & 2,422 \\
\hline
\end{tabular}

Berdasarkan tabel coeficient di atas dapat dijelaskan bahwa pada bagian colinieritas statistic menunjukkan angka VIF tidak lebih besar dari 10 dan tolerance lebih dari 0,10 . Berdasarkan hasil tersebut dapat diketahui bahwa model regresi substruktural II ini tidak terdapat multikolinieritas, sehingga model dapat dipakai. 


\section{Uji Heterokedastisitas}

Pengujian ini dilakukan untuk menguji apakah dalam sebuah model regresi tidak terjadi ketidaksamaan varian dan residual disuatu pengamatan yang lain. Hasil analisis diperoleh hasil model regresi substruktural I dalam penelitian ini tidak terjadi heterokedastisitas dan model regresi substruktural II dalam penelitian ini tidak terjadi heterokedastisitas.

\section{Uji Normalitas}

Uji ini dilakukan untuk menguji apakah data sebuah model regresi, variabel dependen atau keduanya mempunyai distribusi normal atau mendekati normal. Adapun hasil analisisnya adalah model substruktural I dan substruktural II memenuhi asumsi normalitas.

\section{Analisis Jalur}

Persamaan struktural I sebagai berikut :

$Y_{l}=0,461 X_{1}+0,398 X_{2}+€_{1}$

Persamaan struktural II sebagai berikut :

$Y_{2}=0,099 X_{1}+0,252 X_{2}+0,503 Y_{1}+€_{2}$

Keterangan :

$\mathrm{Y}_{1}=$ Shopping Emotion

$\mathrm{Y}_{2}=$ Pembelian Impulsif

$\mathrm{X}_{1}=$ E-servicescape

$\mathrm{X}_{2}=$ Advertising Effectiveness

$\varepsilon_{1}=$ Nilai Residu struktural I

$\varepsilon_{2}=$ Nilai Residu struktural II

Diagram jalur

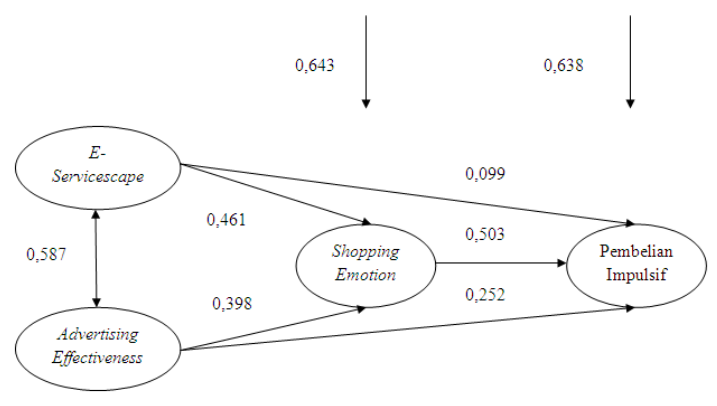

\section{Uji Parsial (Uji t)}

\section{Tabel IV.13 \\ Hasil Uji t Substruktural I Coefficients $^{\mathrm{a}}$}

\begin{tabular}{|c|c|c|c|c|c|c|}
\hline & \multirow{3}{*}{ Model } & \multirow{2}{*}{\multicolumn{2}{|c|}{$\begin{array}{c}\text { Unstandardized } \\
\text { Coefficients } \\
\end{array}$}} & \multirow{3}{*}{$\begin{array}{c}\text { Standardized } \\
\text { Coefficients } \\
\text { Beta }\end{array}$} & \multirow{3}{*}{$\mathrm{T}$} & \multirow{3}{*}{ Sig. } \\
\hline & & & & & & \\
\hline & & $\mathrm{B}$ & Std. Error & & & \\
\hline \multirow{3}{*}{1} & (Constant) & -.307 & .785 & & -.392 & .696 \\
\hline & $\mathrm{X} 1$ & .358 & .063 & .461 & 5.726 & .000 \\
\hline & $\mathrm{X} 2$ & .295 & .060 & .398 & 4.945 & .000 \\
\hline
\end{tabular}

1. Hasil uji t pada tabel di atas menunjukan bahwa probabilitas signifikansi untuk variabel $E$ Servicescape $\left(\mathrm{X}_{1}\right)$ sebesar 0,000 $<0,05$ dan hasil perhitungan diperoleh angka $\mathrm{t}$ penelitian sebesar $5,726>\mathrm{t}$ tabel sebesar 1,985 maka $\mathrm{H}_{0}$ ditolak sedangkan $\mathrm{H}_{1}$ diterima. Artinya, E-Servicescape berpengaruh secara signifikan terhadap Shopping Emotion. Besarnya pengaruh E-Servicescape terhadap Shopping Emotion sebesar 0,461 atau $46,1 \%$.

2. Hasil uji t pada tabel di atas menunjukan bahwa probabilitas signifikansi untuk variabel Advertising Effectiveness $\left(\mathrm{X}_{2}\right)$ sebesar 0,000 $<0,05$ dan hasil perhitungan diperoleh angka $\mathrm{t}$ penelitian sebesar 4,945 > t tabel sebesar 1,985 maka $\mathrm{H}_{0}$ ditolah sedangkan $\mathrm{H}_{1}$ diterima. Artinya, Advertising Effectiveness berpengaruh secara signifikan terhadap Shopping Emotion. Besarnya pengaruh Advertising Effectiveness terhadap Shopping Emotion sebesar 0,398 atau $39,8 \%$.

Tabel IV.14

Hasil Uji t Substruktural II Coefficients $^{\mathrm{a}}$

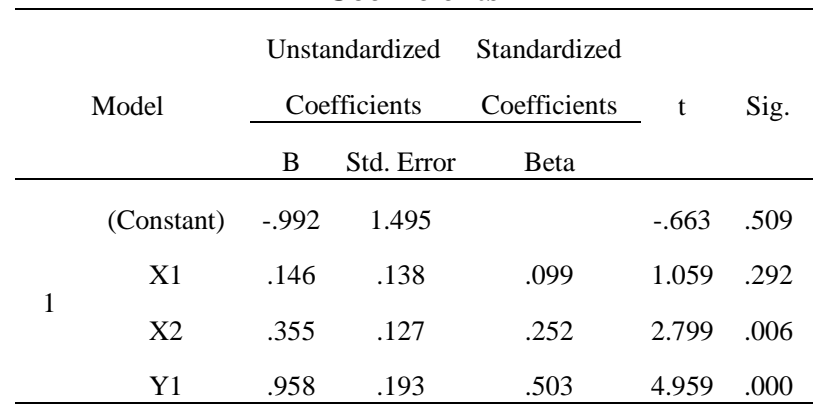

3. Hasil uji t pada tabel di atas menunjukan bahwa probabilitas signifikansi untuk variabel $E_{\text {- }}$ Servicescape $\left(\mathrm{X}_{1}\right)$ sebesar 0,292 >0,05 dan hasil perhitungan diperoleh angka $\mathrm{t}$ penelitian sebesar $1,059<\mathrm{t}$ tabel sebesar 1,985 maka $\mathrm{H}_{0}$ diterima sedangkan $\mathrm{H}_{1}$ ditolak. Artinya, E-Servicescape tidak berpengaruh secara signifikan terhadap pembelian impulsif. Besarnya pengaruh E-Servicescape terhadap pembelian impulsif sebesar 0,099 atau 9,9\%.

4. Hasil uji t pada tabel di atas menunjukan bahwa probabilitas signifikansi untuk variabel Advertising Effectiveness $\left(\mathrm{X}_{2}\right)$ sebesar 0,006 $<0,05$ dan hasil perhitungan diperoleh angka $\mathrm{t}$ penelitian sebesar 2,799 > t tabel sebesar 1,985 maka $\mathrm{H}_{0}$ ditolak sedangkan $\mathrm{H}_{1}$ diterima. Artinya, Advertising Effectiveness berpengaruh secara signifikan terhadap pembelian impulsif. Besarnya pengaruh Advertising Effectiveness terhadap pembelian impulsif sebesar 0,252 atau $25,2 \%$

5. Hasil uji t pada tabel di atas menunjukan bahwa probabilitas signifikansi untuk variabel Shopping Emotion $\left(\mathrm{Y}_{1}\right)$ sebesar $0,000<0,05$ dan hasil perhitungan diperoleh angka $\mathrm{t}$ penelitian sebesar 4,959 > t tabel sebesar 1,985 maka $\mathrm{H}_{0}$ ditolak sedangkan $\mathrm{H}_{1}$ diterima. Artinya, Shopping Emotion berpengaruh secara signifikan terhadap pembelian impulsif. Besarnya pengaruh Shopping Emotion 
terhadap pembelian impulsif sebesar 0,503 atau $50,3 \%$.

\section{PENUTUP}

\section{Simpulan}

Berdasarkan hasil analisis data yang terkumpul dapat diambil kesimpulan sebagai berikut :

1. Hasil penelitian ini menunjukkan bahwa variabel $E$ Servicescape berpengaruh secara signifikan terhadap Shopping Emotion di Shopee, dengan pengaruh sebesar $46,1 \%$ dan sisanya dipengaruhi oleh variabel lain. Hal ini dapat disimpulkan bahwa E-Servicescape memiliki pengaruh yang positif terhadap Shopping Emotion di Shopee.

2. Hasil penelitian ini menunjukkan bahwa variabel Advertising Effectiveness berpengaruh secara signifikan terhadap Shopping Emotion di Shopee, dengan pengaruh sebesar 39,8\% dan sisanya dipengaruhi oleh variabel lain. Hal ini dapat disimpulkan bahwa Advertising Effectiveness memiliki pengaruh yang positif terhadap Shopping Emotion di Shopee

3. Hasil penelitian ini menunjukkan bahwa variabel $E$ Servicescape tidak berpengaruh secara signifikan terhadap Pembelian Impulsif di Shopee yakni hanya sebesar 9,9\%. Hal ini dapat disimpulkan bahwa $E$ Servicescape tidak memiliki pengaruh yang signifikan terhadap Pembelian Impulsif di Shopee

4. Hasil penelitian ini menunjukkan bahwa variabel Advertising Effectiveness berpengaruh secara signifikan terhadap Pembelian Impulsif di Shopee dengan pengaruh sebesar $25,2 \%$ dan sisanya dipengaruhi oleh variabel lain. Hal ini dapat disimpulkan bahwa Advertising Effectiveness memiliki pengaruh yang positif terhadap Pembelian Impulsif di Shopee

5. Hasil penelitian ini menunjukkan bahwa variabel Shopping Emotion berpengaruh secara signifikan terhadap Pembelian Impulsif di Shopee, dengan pengaruh sebesar 50,3\% dan sisanya dipengaruhi oleh variabel lain. Hal ini dapat disimpulkan bahwa Shopping Emotion memiliki pengaruh yang positif terhadap Pembelian Impulsif di Shopee

\section{Saran}

Berdasarkan kesimpulan yang telah dipaparkan, penulis memberikan saran sebagai berikut :

1. E-Servicescape terbukti memberikan pengaruh yang positif serta signifikan terhadap Shopping Emotion pada pengguna Shopee. Oleh karena itu, perlu adanya perhatian khusus terhadap kualitas website dan aplikasi yang dilakukan pihak marketplace, baik itu maintenance, peningkatan kualitas maupun pembaharuan terhadap website dan aplikasi itu sendiri.

2. Advertising Effectiveness terbukti memberikan pengaruh yang positif serta signifikan terhadap Shopping Emotion pada pengguna Shopee. Tanyangantanyangan iklan yang ditawarkan diberbagai platform ternyata efektif memberikan pengaruh terhadap Shopping Emotion dalam diri seseorang. Menggunakan tema yang sedang digemari atau penggunaan bintang iklan yang sedang bersinar dapat menjadi pilihan dalam pembuatan iklan yang efektif.

3. Shopping Emotion terbukti memberikan pengaruh yang positif serta signifikan terhadap Pembelian Impulsif pada pengguna Shopee. Rangsangan terhadap emosi seseorang terlebih dalam proses berbelanja ternyata dapat berimbas pada perilaku Pembelian Impulsif. Pemberian rangsangan secara baik atau berkala dapat terus ditingkatkan guna meningkatkan perilaku Pembelian Impulsif. Pemberian rangsangan yang dapat diberikan antara lain dengan fokus pada e-servicescpe, yang dapat dilakukan dengan memperhatikan nilai estetika pada tampilan website dan aplikasi yang dapat menarik perhatian pengguna. Ini pastinya akan menguntukan bagi pelaku usaha marketplace.

\section{DAFTAR PUSTAKA}

Abdurrahman, Adi Sukma. 2012. Analisis Faktor-Faktor Yang Mempengaruhi Keputusan Pembelian Melalui Social Networking Websites. Fakultas Ekonomi, Universitas Gunadarma

Adawiyah, Qori'atul, at all . 2018. Triggering Impulsive Buying Based on Brand Personality, Promotion and Servicescape with Mediation Shopping Emotion. Jurnal Universitas Jember.

Allan, Dwi I'sana. 2013. Analisis Pengaruh Display produk, Promosi Below The Line, dan Emosi Positif Terhadap Keputrusan pembelian Impulsif Pada Sri Ratu Pemuda Department Store. Jurnal Undip

C. Mowen, John. Michael Minor. 2002. Perilaku Konsumen. Jakarta. Erlangga

Djaslim, Saladin dan Yevis Marty Oesman. 2002. Intisari Pemasaran dan Unsur - Unsur Pemasaran, Cetakan Kedua. Bandung. Penerbit Linda Karya

Durianto, Darmadi dan C. Liana. Analisis Efektivitas Iklan Televisi Softener Soft \& Fresh di Jakarta dan Sekitarnyadengan Menggunakan Consumer Decision Model. Jurnal Ekonomi Perusahaan, Vol. 11, No. 1, 2004

Engel, J. F., \& Blackwell, R. D. 1982. Consumer Behavior. Fourth Edition. Chicago, The Dryden Press 
Ghozali, Imam. 2013. Aplikasi Analisis Multivariate dengan Program IBM SPSS 21 Update PLS Regresi. Semarang: Badan Penerbit Universitas Diponegoro.

Griffin, W, Ricky dan Ronald J Ebert. 2002. Management, Erlangga, Jakarta.

Harris, L. C., and M. M. H. Goode. 2010. Online Servicescape, Trust, and Purchase Intentions. Journal of Service Marketing, Vol. 24, No. 3: hal. 230-243

Haryanto, S. 2009. Ensiklopedi Tanaman Obat Indonesia. Yogyakarta: Palmal.

Hawkins. et al. 2001. Consumer Behavior: Building Market Strategy. Boston : Irwin/Mc Graw Hill

Japarianto, Edwin \& Sugiyono Sugiharto. 2011. Pengaruh Shopping Lifestyle dan Fashion Involvement Terhadap Impulse Buying Behavior Masyarakat High Income Surabaya. Jurnal Manajemen Pemasaran, Vol.6, No. 1

Kurniawan, Denny Kurniawan dan Yohanes Sondang Kunto Ssi. Msc (2013). Pengaruh Promosi dan Store Atmosphere terhadap Impulse Buying dengan Shopping Emotion sebagai Variabel Intervening Studi Kasus di Matahari Departemen Store Cabang Supermall Surabaya. Jurnal Universitas Kristen Petra.

Mowen, John C. and Michael Minor. 2001. Perilaku Konsumen. Alih bahasa: Dwi Kartini Yahya. Jilid 2: Jakarta: Erlangga.

Rao, Purba. 1996. Measuring Consumer Perception Throught Factor Analysis. The AsiaManager. February-March. Hal 28-32

Rook, D dan Fisher, J.R.1995, Normative influences on impulsive buying behaviour", in Bearden, W. And Netemeyer, G.R. (Eds), Handbook of Marketing Scales,2nd ed, pp.55-56

Rook, D dan Fisher, J.R. 1995. Normative influences on impulsive buying behavior. Journal of consumer research, pp.305-313

Sarwono, Jonatan. 2007. SPSS Analisis Jalur. Yogyakarta: Penerbit Andi

Simamora, Bilson. (2007). Panduan Riset dan Perilaku Konsumen. Jakarta :PT Gramedia Pustaka Utama

Simamora, Bilson. 2004. Membongkar Kotak Hitam. Jakarta: Gramedia Pustaka Utama.Shimp, Terence. 2000. Periklanan Promosi: Aspek Tambahan Komunikasi Pemasaran Terpadu, edisi ke-5. Jakarta: Erlangga

Sugiyono. 2010. Statistika untuk Penelitian. Bandung: Alfabeta

Suliyanto. 2011. Ekonomika Terapan: Teori dan Aplikasi dengan SPSS. Yogyakarta:Penerbit Andi.
Tjiptono, Fandy. 2005. Pemasaran Jasa, Edisi Pertama, Yogyakarta; Penerbit Bayumedia Publishing

Utami, Christina Widya. 2010. Manajemen Ritel (edisi 2). Jakarta:Salemba Empat.

Wauran, Pricylia dan Jane Grace Poluan (2016). Pengaruh Promosi Penjualan Dan Servicescape Terhadap Impulse Buying Dengan Shopping Emotion Sebagai Variabel Intervening (Studi Pada Konsumen Freshmart Manado). Jurnal Universitas Sam Ratulangi.. 